A C G

Rec. Nat. Prod. 15:3 (2021) 175-186

records of natural

publications

products

\title{
Chemical Composition and Assessment of Antimicrobial, Antioxidant and Antiproliferative Activities of Essential oil from Clinopodium sericeum, a Peruvian Medicinal Plant
}

\author{
Julio Benites $\oplus^{1,2^{*}}$, David Ríos $\oplus^{1}$, Angélica Guerrero-Castilla $\oplus^{1}$, Cinthya \\ Enríquez $\oplus^{1,2}$, Ewaldo Zavala $\oplus^{2}$, Roberto O. Ybañez-Julca $\oplus^{2}$, \\ Ivan Quispe-Díaz $\oplus^{2}$, Rafael Jara-Aguilar $\oplus^{2}$ and \\ Pedro Buc Calderon $\oplus^{1,3}$
}

${ }^{\text {I} Q u i ́ m i c a ~ y ~ F a r m a c i a, ~ F a c u l t a d ~ d e ~ C i e n c i a s ~ d e ~ l a ~ S a l u d, ~ U n i v e r s i d a d ~ A r t u r o ~ P r a t, ~ C a s i l l a ~ 121, ~ I q u i q u e ~}$

1100000, Chile

${ }^{2}$ Facultad de Farmacia y Bioquímica, Universidad Nacional de Trujillo, 13011 Trujillo, Perú

${ }^{3}$ Research Group in Metabolism and Nutrition, Louvain Drug Research Institute, Université catholique

de Louvain, 73 Avenue E. Mounier, 1200 Brussels, Belgium

(Received October 12, 2020; Revised November 09, 2020; Accepted November 14, 2020)

\begin{abstract}
Clinopodium sericeum is widely used in Peruvian folk medicine in the form of infusion to treat stomach distress, indigestion and antiflu. In this study, the essential oil from $C$. sericeum was obtained by hydrodistillation, analyzed by GC and GC/MS, and 73 compounds were identified. Major components of the oil were $\beta$-germacrene-D (15\%), $\beta$-caryophyllene (13.8\%), and sabinene (11.2\%). Furthermore, we assessed the in vitro biological activities displayed by the oil obtained from the aerial parts of $C$. sericeum, namely the antioxidant, antimicrobial and antiproliferative activities. The antioxidant activities of the essential oil were evaluated by FRAP, CUPRAC, ABTS and DPPH radical scavenging activity. The essential oil displays antibacterial activity against Gram-negative and Gram-positive bacterial strains (MIC 50-200 $\mu \mathrm{g} / \mathrm{mL}$ ) in a dose-range close to standard antibiotics. Such activity may be related to the presence of terpene compounds. The antiproliferative activity of the essential oil was measured in vitro using the MTT colorimetric assay in healthy non-tumorigenic cells (HEK-293) and in three human cancer cell lines (T24, DU-145, and MCF-7). The calculated $\mathrm{IC}_{50}$ values were around $0.2 \mathrm{mg} / \mathrm{mL}$. Since the essential oil was almost devoid of antioxidant activity, its anti-proliferative action is unlikely related to oxidative stress and relies on other unknown mechanisms.
\end{abstract}

Keywords: Folk medicine; Clinopodium sericeum; antioxidant; antimicrobial; antiproliferative; cancer cells. (C) 2020 ACG Publications. All rights reserved.

\section{Introduction}

Essential oils are volatile compounds extracted from the leaves, flowers, fruits, stalks, roots and resins of plants. Plant essential oils and their components have longtime been used for their numerous

\footnotetext{
*Corresponding author: E-Mail: juliob@unap.cl (J.Benites) pedro.buccalderon@uclouvain.be (Pedro Buc Calderon) Phone: +56 572416682 Fax: +56572416685
} 
biological activities such as antimicrobial $[1,2,3]$, antioxidant $[3,4,5]$ and cytotoxic activities $[3,5,6]$. The components of essential oils include terpene hydrocarbons, alcohols, aldehydes, ketones, and esters [7,8]. Such chemical constituents are widely used in aromatherapy, perfumes, cosmetics, and food industry [9].

During the last decade, we have explored the biological properties of several medicinal plants commonly used by the Chilean and Peruvian Andean highlands communities [10-14]. In this work, we focus on the genus Clinopodium, Lamiaceae familiy, one of the richest species among the Angiosperms that includes 135 perennial herbs [15] and is frequently used for its medicinal properties. Clinopodium sericeum (C. Presl ex Benth.) Govaerts, a plant collected in the region of Cajamarca (Perú), was selected because its use by natives in folk medicine in the form of infusion for digestive disorders (stomach distress and indigestion) and antiflu. This herb is known by the vernacular name "romerito de campo" [16].

To our knowledge, the essential oil chemical composition of Clinopodium sericeum has not been investigated. Therefore, using a double approach gas chromatography-mass spectrometry (GC-MS), the present study aimed at determining the essential oil composition of Clinopodium sericeum. In addition, we assessed the potential biological activities of the essential oil. To this end, first, we investigated the antimicrobial capacity of Clinopodium sericeum essential oil against a panel of human pathogenic bacteria: two Gram-positive (Staphylococcus aureus and Enterococcus faecalis), and three Gram-negative (Klebsiella pneumoniae, Pseudomonas aeruginosa and Escherichia coli). Second, we measured the polyphenolic content total phenolic (TP) and the antioxidant activities: ferric-reducing antioxidant power (FRAP), cupric-reducing antioxidant power (CUPRAC), 2,2'-azino-bis (3-ethylbenzothiazoline-6sulfonic acid) (ABTS) and 2,2-diphenyl-1-picrylhydrazyl (DPPH) radical scavenging activity of essential oil. Finally, in order to assess its antiproliferative activity, the in vitro cytotoxicity of essential oil was tested against a panel of three human-derived cancer cell lines and non-tumor fibroblast kidney cells.

\section{Materials and Methods}

\subsection{Plant Material}

Clinopodium sericeum (C.Presl ex Benth.) Govaerts., plants were collected in January 2019 at $2648 \mathrm{~m}$ above sea level. Once collected, the specimens were identified from the "Herbarium Truxillense de la Facultad de Ciencias Biológicas de la Universidad Nacional de Trujillo". A voucher sample under accession HUT 59478 was deposited in this herbarium.

\subsection{Essential Oil Isolation}

Fresh aerial parts $(50 \mathrm{~g})$ were subjected to hydrodistillation for $3 \mathrm{~h}$ using a Clevenger-type apparatus. The obtained oil was dried over anhydrous sodium sulfate. Afterwards, it was filtered, stored under protection at $+4^{\circ} \mathrm{C}$ until analysis and further testing.

\subsection{Gas chromatography Analysis (GC)}

All chemicals used were of analytical reagent grade. All reagents were purchased from SigmaAldrich-Fluka (St. Louis, MO, USA), Merck (Darmstadt, Germany) and were used as supplied.

The essential oil was analyzed on a Perkin Elmer Clarus 400 gas chromatograph. It was equipped with two flame ionization detectors (FIDs), a data handling system and a vaporizing injector port into which two columns of different polarities were set. A DB-1 fused-silica column (polydimethylsiloxane, $30 \mathrm{~m}$ x $0.25 \mathrm{~mm}$ i.d., film thickness $0.25 \mu \mathrm{m}$; J \& W Scientific Inc., Rancho Cordova, CA, USA) and a DB-17HT fused-silica column [(50\% phenyl)-methylpolysiloxane, $30 \mathrm{~m} \times 0.25 \mathrm{~mm}$ i.d., film thickness $0.15 \mu \mathrm{m}$; J \& W Scientific Inc.]. Oven temperature was programmed, $45-175^{\circ} \mathrm{C}$, at $3^{\circ} \mathrm{C} / \mathrm{min}$, subsequently at $15^{\circ} \mathrm{C} / \mathrm{min}$ up to $300^{\circ} \mathrm{C}$, and then held isothermal for $10 \mathrm{~min}$; injector and detector temperatures, $280^{\circ} \mathrm{C}$ and $300^{\circ} \mathrm{C}$, respectively; carrier gas, hydrogen, adjusted to a linear velocity of $30 \mathrm{~cm} / \mathrm{s}$. The samples were injected using split sampling technique, ratio 1:50. The volume of injection was $0.1 \mu \mathrm{L}$ of a pentane-oil solution (1:1). The percentage composition of the oil was calculated by the normalization method from the GC peak areas, calculated as mean values of two injections from oil, without using correction factors. 


\subsection{Gas Chromatography-Mass Spectrometry (GC-MS)}

The GC-MS analysis of the essential oil was conducted on a Perkin Elmer Clarus 600 gas chromatograph, equipped with DB-1 fused-silica column (30 m x $0.25 \mathrm{~mm}$ i.d., film thickness $0.25 \mu \mathrm{m}$; J \& W Scientific, Inc.), and interfaced with a Perkin-Elmer Clarus 600T mass spectrometer (software version 4.1, Perkin Elmer, Shelton, CT, USA). Injector and oven temperatures were as above; transfer line temperature, $280^{\circ} \mathrm{C}$; ion source temperature, $220^{\circ} \mathrm{C}$; carrier gas, helium, adjusted to a linear velocity of $30 \mathrm{~cm} / \mathrm{s}$; split ratio, 1:40; ionization energy, $70 \mathrm{eV}$; scan range, 40-300 m/z; scan time, $1 \mathrm{sec}$. The identity of the components was assigned by comparison of their retention indices, relative to $\mathrm{C}_{9}-\mathrm{C}_{21} \mathrm{n}$ alkane indices and GC-MS spectra from a homemade library, constructed based on the analyses of reference oils, laboratory-synthesized components and commercial available standards.

\subsection{Antimicrobial Activity}

Two techniques were used to test the antimicrobial activity of the Clinopodium sericeum oil: the paper disc diffusion and the dilution broth methods. The minimum inhibitory concentration (MIC) was determined by the latter method.

\subsubsection{Bacterial Strains}

The microorganisms used were Staphylococcus aureus (ATCC 25923), Enterococcus faecalis (ATCC 29212), Klebsiella pneumoniae (ATCC 700603), Pseudomonas aeruginosa (ATCC 27853) and Escherichia coli (ATCC 25922).

\subsubsection{Paper Disc Diffusion}

The antimicrobial activity was carried out according to the disc diffusion assay [17], the bacterial strains were maintained in agar at room temperature. Two point five $\mathrm{mL}$ of every bacteria inoculum were incubated in Mueller-Hinton agar at $37^{\circ} \mathrm{C}$ for 18 hours. The bacterial inoculum was adjusted to the McFarland $\mathrm{N}^{\circ} 0.5$ turbidity standard $(10 \mathrm{cfu} / \mathrm{mL})$. Every inoculum was spread over plates containing Mueller-Hinton agar and a filter paper disc. The plates were left for $30 \mathrm{~min}$ at room temperature and they were further incubated for $24 \mathrm{~h}$ at $37^{\circ} \mathrm{C}$. The inhibitory zone around the disc was measured and it was expressed in mm. A positive control was also included to check the sensitivity of the tested organisms using the antibiotics ceftazidime and clindamycin. A negative control was also included in the test using a filter paper disc saturated with dimethylsulfoxide (DMSO) to check possible activity of this solvent against the bacteria assayed. The experiments were performed at least three times.

\subsubsection{Determination of the Minimum Inhibitory Concentration (MIC)}

The antimicrobial activity of the essential oil was determined by the broth dilution method [17]. The following concentrations were tested: 200, 100, 50, 25, and $12.5 \mu \mathrm{g} / \mathrm{mL}$. After incubation, the microbial growth was examined. The results are expressed in Minimum Inhibitory Concentration (MIC), the lowest concentration of essential oil yielding no visible growth. The bactericidal/bacteriostatic activity was determined by sub-cultivation of the samples in normal culture media at appropriate temperature and incubation times. The MIC of each essential oil was performed in triplicate. The essential oil was dissolved in DMSO (Merck). Ceftriaxone was used as a positive control, at the same essential oil concentration.

\subsection{Total Phenolic Contents (TPC)}

The total phenolic content of the essential oil was estimated using the Folin-Ciocalteu method adapted from Singleton and Rossi [18]. To $25 \mu \mathrm{L}$ of diluted essential oil, was added followed by $125 \mu \mathrm{L}$ 
of Folin-Ciocalteu solution. After 20 minutes, $100 \mu \mathrm{L}$ sodium carbonate $(7 \%)$ was added. The whole mixture was incubated at $45^{\circ} \mathrm{C}$ for 10 minutes. A deep blue coloration developed whose absorbance was read at $760 \mathrm{~nm}$. Results are expressed as $\mathrm{mg}$ of gallic acid equivalent $(\mathrm{GAE}) / \mathrm{mL}$ of essential oil.

\subsection{Antioxidant Capacity Assays}

The FRAP and CUPRAC assays were carried out as previously described [19] with some modifications. Briefly, the FRAP the stock solutions included $300 \mathrm{mM}$ acetate buffer $\mathrm{pH} 3.6,10 \mathrm{mM}$ TPTZ (2,4,6-tripyridyl-S-triazine) solution in $40 \mathrm{mM} \mathrm{HCl}$, and $20 \mathrm{mM} \mathrm{FeCl}_{3} \times 6 \mathrm{H}_{2} \mathrm{O}$ solution. The working solution was prepared by mixing $25 \mathrm{~mL}$ acetate buffer, $2.5 \mathrm{~mL}$ TPTZ solution, and $2.5 \mathrm{~mL} \mathrm{FeCl}_{3}$ x $6 \mathrm{H}_{2} \mathrm{O}$ solution and then warmed at $37^{\circ} \mathrm{C}$ before using. The stock solution of $0.5 \mathrm{mM}$ of the Trolox ${ }^{\circledR}$ was prepared. From this stock solution, serial dilutions (0.05, 0.1, 0.2, 0.3, 0.4 and $0.5 \mathrm{mM})$ were made. Essential oil $(8 \mu \mathrm{L})$ were allowed to react with $200 \mu \mathrm{L}$ of the fresh FRAP solution for $30 \mathrm{~min}$ in the dark. Readings of the colored product ferrous tripyridyltriazine complex were then taken at $593 \mathrm{~nm}(\mathrm{n}=3)$. The standard curve was performed with the standard antioxidant Trolox®. The CUPRAC assay was carried by mixing $250 \mu \mathrm{L}$ ammonium acetate $(\mathrm{pH} 7.0)$ with $250 \mu \mathrm{L} \mathrm{CuCl}_{2}$ and $250 \mu \mathrm{L}$ Neocuproine solution in a 1:1:1 proportion. Antioxidant standard solution/sample $(10 \mu \mathrm{L})$ and $265 \mu \mathrm{L} \mathrm{H}_{2} \mathrm{O}$ were added to the initial mixture. The reaction was stopped, and the reduction of the cupric ion was measured at $450 \mathrm{~nm}$ after 30 min incubation in the dark. In the FRAP and CUPRAC assays, the results were expressed as $\mathrm{mg}$ of TE (Trolox ${ }^{\circledR}$ equivalents)/mL of essential oil.

The scavenging of the $\mathrm{ABTS}^{-+}$radical was carried out according to Re et al. [20]. Briefly, Trolox ${ }^{\circledR}$ solution was first dissolved in ethanol $(\mathrm{EtOH})$ to a final concentration of $1 \mathrm{mg} / \mathrm{mL}$ and then, it was kept in the dark. The stock solutions were serially diluted in 96-well microplates to final concentrations of $50,100,200,300,400,600,700$ and $800 \mu \mathrm{M}$. Then, $10 \mu \mathrm{L}$ of each dilution mixed with $300 \mu \mathrm{L}$ ABTS radical cation solution, and the reaction mixture was measured at $750 \mathrm{~nm}$ in Fisherbrand accuSkan GO UV/Vis Microplate Spectrophotometer (Hampton, USA). For the essential oil analysis, the same procedure was carried out, changing the $10 \mu \mathrm{L}$ of Trolox ${ }^{\circledR}$ for $10 \mu \mathrm{L}$ of essential oil. Afterwards, a curve of $\% \mathrm{ABTS}^{*+}$ radical versus concentration was plotted and $\mathrm{IC}_{50}$ values were calculated. $\mathrm{IC}_{50}$ denotes the concentration of sample required to scavenge $50 \%$ of ABTS radical cation.

Free radical scavenging activity of compounds were determined by using a stable free radical, namely DPPH (2,2-diphenyl-1-picrylhydrazyl), according to a slightly modified method of of the literature [21]. Trolox ${ }^{\circledR}$ solution was first dissolved in $\mathrm{EtOH}$ to a final concentration of $1 \mathrm{mg} / \mathrm{mL}$ and it was further kept in the dark. The stock solutions were serially diluted in 96-well microplates to final concentrations of $1,0.8,0.6,0.4,0.2$ and $0.1 \mathrm{mM}$. Then, $20 \mu \mathrm{L}$ of each dilution mixed with $300 \mu \mathrm{L}$ DPPH radical solution, and the reaction mixture was incubated for $30 \mathrm{~min}$ at room temperature and absorbance was measured at $517 \mathrm{~nm}$ in Fisherbrand accuSkan GO UV/Vis Microplate Spectrophotometer (Hampton, USA). For the essential oil analysis, the same procedure was carried out, changing the $20 \mu \mathrm{L}$ of Trolox ${ }^{\circledR}$ for $20 \mu \mathrm{L}$ of essential oil. Afterwards, a curve of \% DPPH bleaching activity versus concentration was plotted and $\mathrm{IC}_{50}$ values were calculated. $\mathrm{IC}_{50}$ denotes the concentration of sample required to scavenge 50\% of DPPH free radicals. All assays were performed in triplicate and are reported as mean values $\pm \mathrm{SD}$.

\subsection{Cellular Assays}

\subsubsection{Cell Lines and Cell Cultures}

Human cancer cell lines bladder (T24), prostate (DU-145), breast (MCF-7) and non-tumor HEK293 cells were obtained from the American Type Culture Collection (ATCC, Manassas, VA, USA). The cultures were maintained at a density of $1-2 \times 10^{5}$ cells $/ \mathrm{mL}$ and the medium was changed at 48 - to $72-\mathrm{h}$ intervals. They were cultured in high-glucose Dulbecco's modified Eagle medium (Gibco, Grand Island, NY, USA) supplemented with $10 \%$ fetal calf serum, penicillin $(100 \mathrm{U} / \mathrm{mL})$, and streptomycin $(100$ $\mu \mathrm{g} / \mathrm{mL}$ ). All cultures were kept at $37^{\circ} \mathrm{C}$ in $95 \%$ air $/ 5 \% \mathrm{CO}_{2}$ at $100 \%$ humidity. Phosphate-buffered saline (PBS) was purchased from Gibco. Cells were incubated at the indicated times at $37^{\circ} \mathrm{C}$ with or without essential oil at various concentrations. 


\subsubsection{Cell Survival Assays}

The cytotoxicity of the essential oil was assessed by following the reduction of MTT (3-(4,5Dimethylthiazol-2-yl)-2,5-diphenyltetrazolium bromide) to formazan blue [22]. Cells were seeded into 96-well plates at a density of 10000 cells/well for $24 \mathrm{~h}$ and then incubated for $48 \mathrm{~h}$ with or without the essential oil. Doxorubicin was used as standard chemotherapeutic agent (positive control). Cells were first washed twice with warm PBS and subsequently incubated with MTT $(0.5 \mathrm{mg} / \mathrm{mL})$ for $2 \mathrm{~h}$ at $37^{\circ} \mathrm{C}$. Blue formazan crystals were solubilized by adding $100 \mu \mathrm{l} \mathrm{DMSO} /$ well, and the optical density of colored solutions was subsequently read at $550 \mathrm{~nm}$. Results are expressed as \% of MTT reduction compared to untreated control conditions. The $\mathrm{IC}_{50}$ values were calculated using the GraphPad Prism software (San Diego, CA, USA).

\section{Results and Discussion}

Clinopodium sericeum (C. Presl ex Benth) Govaerts plants were collected in the community of Chugur in the province of San Marcos, Department of Cajamarca, Peru. The essential oil of C. sericeum was obtained from hydrodistillation of plant (leaves and steams) and its yield was calculated based on a moisture-free basis as $0.25 \%(\mathrm{w} / \mathrm{w})$.

\subsection{Chemical Composition of Clinopodium sericeum}

Table 1 shows the gas chromatography (GC) and GC-MS analysis of the essential oil of the aerial parts from Clinopodium sericeum (C. Presl ex Benth) Govaerts. We identified the essential oil components by comparing the GC retention indices (RI) on polar and non-polar columns. The components were determined according to the retention time of a series of n-alkanes with linear interpolation with those standards and our essential oils database. The GC analysis of the essential oil revealed seventy-three compounds, accounting for $90.8 \%$ of the total composition (Table 1). Sesquiterpene hydrocarbons were the major constituents (39.2\%), while the monoterpene hydrocarbons were present in concentrations of $22.5 \%$. The oxygen-containing monoterpenes were prevalent $(20.7 \%)$ as compared to oxygen-containing sesquiterpenes (7.6\%). In addition, phenylpropanoids were present in low concentrations in oil $(0.8 \%)$.

The major constituents of the essential oil of Clinopodium sericeum are a natural bicyclic monoterpene, namely sabinene (11.2\%), and the sesquiterpenes, $\beta$-caryophyllene (13.8\%) and germacrene-D (15\%).

Historically, natural products have been used as sources to treat, cure and prevent diseases [23]. The greatest contribution of these natural products occurs through plants, which can be classified according to their chemical constitution, and this classification is defined as chemotaxonomy [24]. The Lamiaceae family has been demonstrated to be full of chemotaxonomic markers at every level: family, subfamily, genus, and species. This statement is mainly true for the polar fraction metabolites.

The essential oil of Lamiaceae species is particularly rich in volatile monoterpenes, sesquiterpenes, and diterpenes, which are constituted with 10, 15, and 20 carbon atoms, respectively. Among monoterpenes, the main compounds are $\alpha$-pinene, $\beta$-pinene, 1,8-cineole, menthol, limonene, and $\gamma$ terpinene [25-30]. Indeed, germacrene D, caryophyllene, and spathulenol represent the main sesquiterpene compounds [31-34]. In fact, concerning essential oils, none of the previously described compounds can really represent a chemotaxonomic marker. This is due to two important reasons: the first one, concerning phytochemistry, reflects how the presence of those compounds has been reported in other families [35-38], and the second one, concerning ecology, underlines that the essential oil content of a species depends largely on environmental factors, and thus does not permit absolute and definitive results $[39,40]$. On the other hand, the polar fraction metabolites present more specific amounts from the chemotaxonomic standpoint. Actually, under this aspect, the chemotaxonomy of Lamiaceae is very complex. 
Table 1. Percentage composition of the Essential Oil isolated from Clinopodium sericeum collected in Cajamarca, Peru.

\begin{tabular}{|c|c|c|c|c|}
\hline Compounds & $\mathbf{R} \mathbf{I}^{\mathbf{a}}$ & $\begin{array}{c}\text { Relative } \\
\text { content }(\%)\end{array}$ & $\begin{array}{c}\text { Identification } \\
\text { method }\end{array}$ & RI data ${ }^{b}$ \\
\hline$\alpha$-Thujene & 924 & 0.4 & RI, MS & $905-948$ \\
\hline$\alpha$-Pinene & 930 & 1.6 & RI, MS & $909-956$ \\
\hline Camphene & 938 & 0.4 & RI, MS & $929-978$ \\
\hline Sabinene & 958 & 11.2 & RI, MS & 944-980 \\
\hline$\beta$-Pinene & 963 & 4.1 & RI, MS & $952-986$ \\
\hline Myrcene & 975 & 0.2 & RI, MS & $962-993$ \\
\hline$\alpha$-Phellandrene & 995 & $\mathrm{t}$ & RI, MS & $985-1019$ \\
\hline$\alpha$-Terpinene & 1002 & 0.1 & RI, MS & $1003-1024$ \\
\hline$\beta$-Phellandrene & 1005 & 0.1 & RI, MS & $1007-1045$ \\
\hline Limonene & 1009 & 0.8 & RI, MS & $995-1044$ \\
\hline$p$-Cymene & 1013 & 2.7 & RI, MS & $992-1072$ \\
\hline 1,8-Cineole & 1015 & 0.1 & RI, MS & $1007-1046$ \\
\hline cis- $\beta$-Ocimene & 1017 & 0.1 & RI, MS & $1022-1051$ \\
\hline trans- $\beta$-Ocimene & 1027 & 0.5 & RI, MS & $1032-1054$ \\
\hline$\gamma$-Terpinene & 1035 & 0.2 & RI, MS & $1030-1089$ \\
\hline trans-Sabinene hydrate & 1037 & 0.1 & RI, MS & $1043-1116$ \\
\hline$n$-Octanol & 1045 & 0.2 & RI, MS & $1051-1082$ \\
\hline Terpinolene & 1064 & 0.1 & RI, MS & $1071-1097$ \\
\hline cis-Sabinene hydrate & 1066 & $\mathrm{t}$ & RI, MS & $1043-1116$ \\
\hline Linalool & 1074 & 5.2 & RI, MS & $1078-1107$ \\
\hline Isopentyl isovalerate & 1094 & 0.1 & RI, MS & $1094-1105$ \\
\hline trans-p-2-Menthen-1-ol & 1099 & 0.1 & RI, MS & $1083-1146$ \\
\hline trans-Pinocarveol & 1106 & 0.1 & RI, MS & $1113-1155$ \\
\hline cis-p-2-Menthen-1-ol & 1110 & 0.1 & RI, MS & $1106-1122$ \\
\hline trans-Verbenol & 1114 & 0.1 & RI, MS & $1114-1163$ \\
\hline Menthone & 1120 & 0.1 & RI, MS & $1124-1142$ \\
\hline Isomenthone & 1126 & $\mathrm{t}$ & RI, MS & $1132-1159$ \\
\hline Borneol & 1134 & 1.0 & RI, MS & $1140-1188$ \\
\hline Neomenthol & 1139 & 0.5 & RI, MS & $1153-1176$ \\
\hline Terpinen-4-ol & 1148 & 2.8 & RI, MS & $1141-1206$ \\
\hline Myrtenal & 1153 & 0.6 & RI, MS & $1151-1197$ \\
\hline$\alpha$-Terpineol & 1159 & 0.5 & RI, MS & $1144-1203$ \\
\hline Myrtenol & 1178 & 0.1 & RI, MS & $1170-1198$ \\
\hline cis-Piperitol & 1182 & 0.1 & RI, MS & $1176-1197$ \\
\hline trans-Carveol & 1189 & 0.1 & RI, MS & $1188-1220$ \\
\hline trans-Piperitol & 1189 & 0.3 & RI, MS & $1181-1212$ \\
\hline Octanol acetate & 1189 & 0.4 & RI, MS & $1190-1215$ \\
\hline Carvone & 1210 & 0.4 & RI, MS & $1210-1246$ \\
\hline Piperitone & 1221 & 0.2 & RI, MS & $1223-1268$ \\
\hline 2-Phenyl ethyl acetate & 1228 & 0.1 & RI, MS & 1224 \\
\hline Bornyl acetate & 1265 & 0.6 & RI, MS & $1261-1297$ \\
\hline Thymol & 1275 & 0.1 & RI, MS & $1264-1302$ \\
\hline trans-Pinocarvyl acetate & 1278 & 1.6 & RI, MS & $1295-1300$ \\
\hline Carvacrol & 1286 & 1.4 & RI, MS & $1279-1317$ \\
\hline Myrtenyl acetate & 1290 & 0.1 & RI, MS & 1322 \\
\hline trans-Carvyl acetate & 1325 & 0.2 & RI, MS & $1312-1342$ \\
\hline$\delta$-Elemene & 1332 & $\mathrm{t}$ & RI, MS & $1324-1386$ \\
\hline Citronellyl acetate & 1343 & $\mathrm{t}$ & RI, MS & $1336-1356$ \\
\hline Carvacrol acetate & 1348 & 4.1 & RI, MS & $1353-1391$ \\
\hline Geranyl acetate & 1370 & 0.1 & RI, MS & $1354-1392$ \\
\hline$\alpha$-Ylangene & 1371 & 0.1 & RI, MS & $1350-1406$ \\
\hline
\end{tabular}




\begin{tabular}{|c|c|c|c|c|}
\hline Compounds & $\mathbf{R I}^{\mathbf{a}}$ & $\begin{array}{c}\text { Relative } \\
\text { content }(\%)\end{array}$ & $\begin{array}{c}\text { Identification } \\
\text { method }\end{array}$ & RI data ${ }^{b}$ \\
\hline$\alpha$-Copaene & 1375 & 1.0 & RI, MS & $1351-1407$ \\
\hline$\beta$-Bourbonene & 1379 & 1.0 & RI, MS & 1346-1396 \\
\hline$\beta$-Cubebene & 1385 & 0.1 & RI, MS & $1360-1400$ \\
\hline$\beta$-Elemene & 1388 & 1.3 & RI, MS & $1362-1410$ \\
\hline$\beta$-Caryophyllene & 1414 & 13.8 & RI, MS & $1411-1421$ \\
\hline$\beta$-Copaene & 1426 & 0.6 & RI, MS & $1428-1437$ \\
\hline Geranyl acetone & 1434 & $\mathrm{t}$ & RI, MS & $1442-1468$ \\
\hline$\alpha$-Humulene & 1447 & 2.7 & RI, MS & $1428-1489$ \\
\hline allo-Aromadendrene & 1456 & 0.2 & RI, MS & $1442-1474$ \\
\hline$\gamma$-Muurolene & 1469 & $\mathrm{t}$ & RI, MS & $1449-1502$ \\
\hline Germacrene-D & 1474 & 15.0 & RI, MS & $1451-1519$ \\
\hline$\beta$-Selinene & 1476 & $\mathrm{t}$ & RI, MS & $1436-1497$ \\
\hline Valencene & 1484 & 0.5 & RI, MS & $1458-1495$ \\
\hline Bicyclogermacrene & 1487 & 0.5 & $\mathrm{RI}, \mathrm{MS}$ & $1470-1533$ \\
\hline trans,trans- $\alpha$-Farnesene & 1500 & 0.5 & $\mathrm{RI}, \mathrm{MS}$ & $1499-1522$ \\
\hline$\gamma$-Cadinene & 1500 & 0.2 & $\mathrm{RI}, \mathrm{MS}$ & $1480-1531$ \\
\hline trans-Calamenene & 1505 & $\mathrm{t}$ & RI, MS & $1509-1529$ \\
\hline$\delta$-Cadinene & 1505 & 1.7 & RI, MS & $1486-1563$ \\
\hline trans-Nerolidol & 1549 & 1.3 & RI, MS & $1535-1569$ \\
\hline Spathulenol & 1551 & 2.6 & RI, MS & $1552-1622$ \\
\hline$\beta$-Caryophyllene oxide & 1561 & 2.7 & RI, MS & $1549-1617$ \\
\hline Humulene epoxide & 1580 & 1.0 & $\mathrm{RI}, \mathrm{MS}$ & $1600-1605$ \\
\hline
\end{tabular}

\subsection{Antibacterial Activity of C. sericeum Essential Oil}

We assessed whether essential oil from $C$. sericeum possesses antimicrobial activity. To this end, the antibacterial activity of $C$. sericeum essential oil, obtained from the leaves and stems, was evaluated against human pathogens, two gram-positive ( $S$. aureus and $E$. faecalis) and three gram-negative ( $K$. pneumonia, $P$. aeruginosa and E. coli). Since these microorganisms are different on the morphological and phylogenic levels, we assume that the results obtained with the essential oil will be representative of its intrinsic antibacterial activity.

Table 2 shows the essential oil antibacterial activity against hazardous bacteria, both Grampositive (S. aureus and E. faecalis) and Gram-negative (K. pneumonia, P. aeruginosa and E. coli). Note that antibiotic resistant bacteria have been observed with increasing frequency over the past several decades. Indeed, S. aureus, K. pneumonia, $P$. aeruginosa and $E$. coli have been involved in several human infections and they developed resistance against standard commercial antibiotic [41].

The effect by essential oil on microorganisms was assessed by estimating the size of bacterial growth inhibition diameter, using the paper disc diffusion test. The inhibitory effect of essential oil was less important than that showed by standard antibiotics. Specifically, the diameter obtained by the essential oil at $3 \mathrm{mg} / \mathrm{mL}$ was in the range of $6-7 \mathrm{~mm}$ in Gram-positive bacterial strains as compared with $14-16 \mathrm{~mm}$ obtained by $30 \mu \mathrm{g}$ Clindamycin (CLI). Regarding Gram-negative bacteria, an inhibitory diameter of 6 - 8 $\mathrm{mm}$ was observed in case of essential oil as compared with 12 - $32 \mathrm{~mm}$ with $2 \mu \mathrm{g}$ Ceftazidime (CAZ). Interestingly, Table 2 also shows that the minimum inhibitory concentration (MIC) values of the essential oil was in the range of $50-200 \mu \mathrm{g} / \mathrm{mL}$. These values are $2-4$ times lower in bacterial strains either Gram-positive or Gram-negative when compared with those of Ceftriaxone (CRO). 
Table 2. Paper disc diffusion and minimum inhibitory concentration (MIC) of the essential oil (EO) of Clinopodium sericeum

\begin{tabular}{lcccccc}
\hline Microorganism & Gram $+/-$ & \multicolumn{2}{c}{ Diameter of the Inhibition Zones $(\mathbf{m m})^{\mathbf{a}}$} & \multicolumn{2}{c}{ MIC $(\boldsymbol{\mu g} / \mathbf{m L})$} \\
\cline { 3 - 7 } & & EO $^{\mathbf{b}}$ & CAZ & CLI & EO & CRO \\
\hline Staphylococcus aureus & G+ & $6.0 \pm 0.50$ & - & $16.0 \pm 0.50$ & 200 & 400 \\
Enterococcus faecalis & G+ & $7.0 \pm 0.50$ & - & $14.0 \pm 0.44$ & 100 & N.T. \\
Klebsiella pneumoniae & G- & $6.0 \pm 0.50$ & $12.0 \pm 0.44$ & - & 200 & N.T. \\
Pseudomonas aeruginosa & G- & $8.0 \pm 0.50$ & $32.0 \pm 0.44$ & - & 100 & N.T. \\
Escherichia coli & G- & $7.0 \pm 0.50$ & $16.0 \pm 0.33$ & - & 50 & 200 \\
\hline
\end{tabular}

a The diameter of the inhibition zones (mm), are given as mean values \pm SD of triplicate experiments. ${ }^{\mathrm{b}}$ Diameter of the inhibition zones of the EO of $C$ sericeum (tested volume, $3 \mathrm{mg} / \mathrm{mL}$ ). Positive control: CAZ, Ceftazidime (30 $\mu \mathrm{g})$; CLI, Clindamycin ( $2 \mu \mathrm{g})$; CRO, Ceftriaxone; N.T.: not tested.

We do not have a suitable explanation for such differences in the responses of the tested microorganisms to the essential oils as measured by either the paper disc diffusion test or the MIC calculation. While the first one is frequently used to estimate the bacterial susceptibility against a given compound, the second one (MIC) denotes the lowest concentration of that compound preventing visible bacterial growth. Nonetheless, one potential explanation is that the size of the inhibitory diameter may be influenced, other than the intrinsic antibacterial activity, by the diffusion of the compound within the agar medium due to its physical-chemical properties and molecular configuration.

Gram-negative bacteria are bounded by a cytoplasmic membrane and an outer cell membrane defining a periplasmic compartment, a cell wall structure composed by lipopolysaccharide and outer membrane organization $[42,43]$. Such structural arrangement forms a hydrophilic permeability barrier that provides protection against the effects of toxic agents [44]. Consequently, Gram-negative bacteria may be more resistant to antibiotics than Gram-positive because these latter bacteria do not have a periplasmic compartment. However, the effect of essential oil in both bacterial classes was rather similar.

Although the mechanism of action of terpenes is not fully understood, it is thought to involve membrane disruption by the lipophilic compounds in Gram-negative bacterial strains [45]. Regarding Gram-positive bacteria, essential oil may unfold its antimicrobial effectiveness by cellular metabolic disturbances after its cellular uptake. Alterations such as denaturation of proteins and enzymes, loss in the equilibrium of $\mathrm{K}^{+}$and $\mathrm{H}^{+}$ions, affect the entire cell morphology, leading to microorganism death [46-48]. While the precise mechanism remains poorly understood, such antibacterial activity may be sustained by sabinene, $\beta$-caryophyllene and germacrene-D, as well as other minor components of $C$. sericeum essential oil. Since essential oils are quite complex mixtures containing a large variety of constituents, the observed antimicrobial effect is may result from the activity of several active compounds as well as to potential synergistic effects between them. Thus, this complexity in chemical composition makes it often difficult to explain the biological activities shown by essential oils [49].

\subsection{Total Phenolic Content and Antioxidant Capacity of C. sericeum Essential Oil}

A second purpose was to investigate the putative antioxidant activity of the essential oil. The total phenolic (TP) content and antioxidant activity of essential oil of $C$. sericeum are summarized in Table 3. The TP content of the essential oil of the $C$. sericeum was expressed in Gallic acid equivalent (GAE) units $(\mathrm{mg} / \mathrm{mL}$ of essential oil), and the result revealed low TP content of the essential oil $(54.38 \mathrm{mg} \mathrm{GAE} / \mathrm{mL})$.

In addition, the antioxidant capacity of essential oil of $C$. sericeum were determined by using several chemical-based methodologies. These assays are based on different strategies providing complementary information about the interaction between radicals and essential oil. In the present work, we evaluated the antioxidant activity of the essential oils using four different assays, based on three different chemical mechanisms: including the reducing capacity of the extracts ferric-reducing antioxidant power (FRAP) and cupric ion-reducing antioxidant capacity (CUPRAC) assays, 2,2'-azino-bis-(3ethylbenzothiazoline-6-sulfonic acid) (ABTS) cation radical scavenging and the scavenging of free radicals 2,2-diphenyl-1-picrylhydrazyl (DPPH). 
Table 3. Polyphenolic content and antioxidant activities of essential oil of Clinopodium sericeum

\begin{tabular}{lccccc}
\hline Samples & $\begin{array}{c}\text { TP } \\
\text { (mg GAE/mL) }\end{array}$ & $\begin{array}{c}\text { FRAP } \\
(\mathbf{m g} \text { TEAC/mL) }\end{array}$ & $\begin{array}{c}\text { CUPRAC } \\
(\mathbf{m g} \text { TEAC/mL) }\end{array}$ & $\begin{array}{c}\text { ABTS } \\
\text { IC } 50\end{array}$ & $\begin{array}{c}\text { DPPH } \\
\text { IC }_{\mathbf{5}}\end{array}$ \\
\hline Essential oil & $54.38 \pm 1.28$ & $1.40 \pm 0.05$ & $30.17 \pm 1.60$ & $106.06 \pm 7.92$ & $473.03 \pm 14.11$ \\
Quercetin & - & $1800.0 \pm 0.02$ & $3980.0 \pm 0.35$ & $0.05 \pm 0.04$ & $0.08 \pm 0.01$ \\
Trolox ${ }^{\circledR}$ & - & - & - & $0.09 \pm 0.06$ & $0.09 \pm 0.02$
\end{tabular}

$\mathrm{TP}=$ total phenolic; FRAP $=$ ferric-reducing antioxidant power; CUPRAC $=$ cupric-reducing antioxidant power; $\mathrm{ABTS}=2,2$ ' azinobis (3-ethylbenzothiazoline-6-sulfonic acid); DPPH = 2,2-diphenyl-1-picrylhydrazyl radical; GAE = Gallic acid equivalent; TEAC $=$ Trolox ${ }^{\circledR}$ equivalent antioxidant capacity. Results are expressed as means values \pm SEM $(n=3)$.

The four assays we have employed show that essential oil is rather devoid of an effective antioxidant activity. For instance, in FRAP assay, the results revealed lower reducing activity of the essential oil $(\mathrm{TEAC}=1.40 \mathrm{mg} / \mathrm{mL})$ than the values of reference standards, Quercetin $(\mathrm{TEAC}=1800$ $\mathrm{mg} / \mathrm{mL}$ ). In the CUPRAC assay, weak activity (TEAC $=30.17 \mathrm{mg} / \mathrm{mL}$ ) was observed as compared of reference standard, Quercetin $(\mathrm{TEAC}=3980 \mathrm{mg} / \mathrm{mL}$ ). In the ABTS cation radical scavenging assay, the essential oil of $C$. sericeum displayed weak activity $\mathrm{IC}_{50}$ of $106 \mathrm{mg} / \mathrm{mL}$. The results of DPPH assay demonstrated that the $C$. sericeum essential oil showed a low radical scavenging activity with $\mathrm{IC}_{50}$ of 473 $\mathrm{mg} / \mathrm{mL}$, which was much higher than the $\mathrm{IC}_{50}$ values of reference standards, Quercetin $\left(\mathrm{IC}_{50}\right.$ of 0.08 $\mathrm{mg} / \mathrm{mL})$ and Trolox ${ }^{\circledR}\left(\mathrm{IC}_{50}\right.$ of $\left.0.09 \mathrm{mg} / \mathrm{mL}\right)$. As previously noted with antibacterial activity, essential oils are quite complex mixtures composed of a great variety of compounds, a complexity making difficult to explain their activities. Therefore, many reports on the antioxidant potentials of essential oils often refer to concepts such as synergism, antagonism, and additivity [50]. In our situation, we have determined that essential oil display a weak antioxidant activity.

\subsection{Antiproliferative Activity of C. sericeum Essential Oil}

In addition to ethno-pharmacologic uses and biological activities (i.e. antimicrobial, fungicide, anti-inflammatory), we investigated the potential antiproliferative of essential oils. Table 4 shows the growth inhibitory effect by the essential oil of $C$. sericeum on three human tumor cell lines (T24, DU-145 and MCF-7), and non-tumorigenic fibroblasts (HEK-293). By using the MTT assay, the antiproliferative activity of essential oils was determined and expressed as $\mathrm{IC}_{50}$ values. The essential oil shows no particular sensitivity against cancerous or non-tumor cells with a mean $\mathrm{IC}_{50}$ value around $200 \mu \mathrm{g} / \mathrm{mL}$, a number remote from that Doxorubicin, a currently used antitumor drug. Nevertheless, it is comparable to $\mathrm{IC}_{50}$ values reported for other essential oils [51,52].

Table 4. The cytotoxic activity of the essential oil from Clinopodium sericeum

\begin{tabular}{lcccc}
\hline Treatments & \multicolumn{4}{c}{ Cytotoxic activity $\mathbf{I C}_{50}(\boldsymbol{\mu M})$} \\
\cline { 2 - 4 } & T24 & DU-145 & MCF-7 & HEK-293 \\
\hline Essential oil & $213.40 \pm 4.14$ & $202.50 \pm 0.18$ & $197.80 \pm 5.19$ & $195.90 \pm 7.46$ \\
DOXO & $0.46 \pm 0.08$ & $0.70 \pm 0.02$ & $0.05 \pm 0.003$ & $4.27 \pm 0.34$ \\
\hline ells were seeded into 96 -well plates at a density of 10000 cells/well for $24 \mathrm{~h}$ and then \\
cubated for 48 $\mathrm{h}$ with or without the essential oil. At the end of the incubation, aliquots of \\
ells suspension were taken and the MTT test was performed as described in the \\
xperimental section. Results are expressed as means values \pm SEM $(\mathrm{n}=3)$. DOXO =doxorubicin.
\end{tabular}

A precise mechanism of action of the essential oil in our study remains to be described. Analyzing the chemical structure of the main constituents of the essential oil suggests an unlikely role of oxidative stress - and its subsequent formation of reactive oxygen species (ROS) - in such antiproliferative activities. In addition, the weak antioxidant properties of the essential oil rules out a major role for a potential oxidative-mediated cell injury. Further studies should investigate what molecular mechanisms are involved in the growth inhibitory effects of the essential oil of $C$. sericeum on cancer cells.

\section{Conclusion}

A double approach GC and GC-MS was used to identify the chemical component of the essential oil from $C$. sericeum. The oil was shown to contain sesquiterpene hydrocarbons, monoterpene hydrocarbons, 
oxygenated monoterpenes and oxygenated sesquiterpenes. After its isolation, the antimicrobial, antioxidant, and antiproliferative properties of the oil were investigated. A weak antibacterial, antioxidant and antitumor potential was found.

\section{Acknowledgments}

The authors extend their appreciation to the VRI-UNT and VRII-UNAP for financial support to this study.

\section{Supporting Information}

Supporting information accompanies this paper on http://www.acgpubs.org/journal/records-ofnatural-products

\section{ORCID}

Julio Benites: 0000-0002-8562-0078

David Ríos: 0000-0002-0733-5191

Angélica Guerrero-Castilla: 0000-0002-2061-5200

Cinthya Enríquez: 0000-0002-9839-7389

Ewaldo Zavala: 0000-0002-0422-8059

Roberto O. Ybañez-Julca: 0000-0003-0011-7957

Ivan Quispe-Díaz: 0000-0001-8515-0654

Rafael Jara-Aguilar: 0000-0002-4371-1967

Pedro Buc Calderon: 0000-0003-0483-2624

\section{References}

[1] W. I. Brnawi, N. S. Hettiarachchy, R. Horax, G. Kumar-Phillips and S. Ricke (2019). Antimicrobial activity of leaf and bark cinnamon essential oils against Listeria monocytogenes and Salmonella typhimurium in broth system and on celery, J. Food Process Preserv. e13888.

[2] K. Winska, W. Maczka, J. Łyczko, M. Grabarczyk, A. Czubaszek and A. Szumny (2019). Essential oils as antimicrobial agents-myth or real alternative?, Molecules 24, 2130-2151.

[3] F. Bakkali and S. Averbeck (2008). Biological effects of essential oils-A review, Food Chem. Toxicol. 46, 446-475.

[4] H.Y. Zhang, Y. Gao and P.X. Lai (2017). Chemical composition, antioxidant, antimicrobial and cytotoxic activities of essential oil from Premna microphylla Turczaninow, Molecules 22, 381-392.

[5] C. Yang, H. Chen, H. Chen, B. Zhong, X. Luo and J. Chun (2017). Antioxidant and anticancer activities of essential oil from Gannan navel orange peel, Molecules 22, 1391-1401.

[6] L. Pudziuvelyte, M. Stankevicius, A. Maruska, V. Petrikaite, O. Ragazinskiene, G. Draksiene and J. Bernatoniene (2017). Chemical composition and anticancer activity of Elsholtzia ciliata essential oils and extracts prepared by different methods, Ind. Crop. Prod. 107, 90-96.

[7] F. D. A. Oliveira, L. N. Andrade, E. B. de Sousa and D. P. de Sousa (2014). Anti-ulcer activity of essential oil constituents, Molecules 19, 5717-5747.

[8] T. Fornari, G. Vicente, E. Vazquez, M. R. Garcia-Risco and G. Reglero (2012). Isolation of essential oil from different plants and herbs by supercritical fluid extraction, J. Chromatogr. A 1250, 34-48.

[9] B. Ali, N. A. Al-Wabel, S. Shams, A. Ahamad, S. A. Khan and F. Anwar (2015). Essential oils used in aromatherapy: A systemic review, Asian Pac. J. Trop. Med. 5, 601-611.

[10] L. Rojo, J. Benites, A. Rodriguez, F. Venancio, L. Ramalho, A. Teixeira, S. Feio and M. do Ceu Costa (2006). Composition and antimicrobial screening of the essential oil of Acantholippia deserticola (Phil.ex F. Phil.) Moldenke, J. Essent. Oil Res. 18, 695-697.

[11] L. E. Rojo, J. Benites, J. López, M. Rojas, P. Díaz, E. Pastene and J. Ordoñez (2009). Comparative study on the antioxidant effects and phenolic content of twelve highly consumed medicinal plants from South American Andes. Bol. Latinoam. Caribe Plants Med. Aromat. 8, 498-450.

[12] J. Benites, C. Moiteiro, G. Miguel, L. Rojo, J. López, F. Venâncio, L. Ramalho, S. Feio, S. Dandlen, H. Casanova and I. Torres (2009). Composition and biological activity of the essential oil of Peruvian Lantana camara, J. Chil. Chem. Soc. 54, 379-384.

[13] J. Benites, J. López, L. Rojo, P. Díaz, M. Rojas, F. Venâncio and M. Moiteiro (2011). Chemical composition of the essential oil of the leaves and stems of Xenophillum poposum, Chem. Nat. Compound 46, 988-989. 
[14] J. Benites, C. Moiteiro, A. C. Figueiredo, P. Rijo, P. Buc-Calderon, F. Bravo, S. Gajardo, I. Sánchez, I. Torres and M. Ganoza (2016). Chemical composition and antimicrobial activity of essential oil of peruvian Dalea strobilacea Barneby, Bol. Latinoam. Caribe Plants Med. Aromat. 15, 429-435.

[15] W. Erhard, E. Götz, N. Bödeker and S. Seybold (2014). Zander - Handwörterbuch der Pflanzennamen. 19. Aufl. Eugen Ulmer GmbH und Co., Stuttgart, pp. 576-577.

[16] I. Sánchez (2011). Especies Medicinales de Cajamarca I: Contribución etnobotánica, morfológica y taxonómica. UPAGU y Lumina Copper Fondo Editorial, Cajamarca, Perú. pp. 227-228.

[17] CLSI. (2019). Performance Standards for Antimicrobial Susceptibility Testing. 29th ed. CLSI supplement M100. Wayne, PA: Clinical and Laboratory Standards Institute.

[18] V. L. Singleton and J. Jr. Rossi (1965). Colorimetry of total phenolics with phosphomolybdic phosphotungstic acid reagents, Am. J. Enol. Vitic. 16, 144-153.

[19] S. Baki , A. N. Tufan, M. Altun, F. Özgökçe, K. Güçlü and M. Özyürek (2018). Microwave-Assisted Extraction of Polyphenolics from Some Selected Medicinal Herbs Grown in Turkey, Rec.Nat.Prod. 12, 2939.

[20] R. Re, N. Pellegrini, A. Proteggente, A. Pannala, M. Yang and C. Rice-Evans (1999). Antioxidant activity applying an improved ABTS radical cation decolorization assay, Free Radic. Biol. Med. 26, 1231-1237.

[21] A. Baran, E. Karakılıç, Ö. Faiz and F. Özer (2020). Synthesis of chalcone-containing zinc and cobalt metallophthalocyanines; investigation of their photochemical,DPPH radical scavenging and metal chelating characters, Org. Commun. 13, 65-78.

[22] T. Mosmann (1983). Rapid colorimetric assay for cellular growth and survival: Application to proliferation and cytotoxicity assays, J. Immunol. Meth. 65, 55-63.

[23] L. M. Casanovaa and S. S. Costa (2017). Synergistic interactions in natural products: therapeutic potential and challenges, Rev. Virtual Quím. 9, 575-595.

[24] A. Barbosa Silva Cavalcanti, R. P. Costa Barros, V. C. O. Costa, M. Sobral da Silva, J. Fechine Tavares, L. Scotti and M. T. Scotti (2019). Computer-aided chemotaxonomy and bioprospecting study of diterpenes of the Lamiaceae family, Molecules 24, 3908-3934.

[25] L. Panizzi, G. Flamini, P. L. Cioni and I. Morelli (1993). Composition and antimicrobial properties of essential oils of four Mediterranean Lamiaceae, J. Ethnopharmacol. 39, 167-170.

[26] V. Hajhashemi, A. Ghannadi and B. Sharif (2003). Anti-inflammatory and analgesic properties of the leaf extracts and essential oil of Lavandula angustifolia Mill, J. Ethnopharmacol. 89, 67-71.

[27] B. Bozin, N. Mimica-Dukic, N. Simin and G. Anackov (2006). Characterization of the volatile composition of essential oils of some Lamiaceae spices and the antimicrobial and antioxidant activities of the entire oils, J. Agric. Food Chem. 54, 1822-1828.

[28] A. P. Longaray Delamare, I. T. Moschen-Pistorello, L. Artico, L. Atti-Serafini and S. Echeverrigaray (2007). Antibacterial activity of the essential oils of Salvia officinalis L. and Salvia triloba L. cultivated in South Brazil, Food Chem. 100, 603-608

[29] A. I. Hussain, F. Anwar, T. Iqbal and I. A. Bhatti (2011). Antioxidant attributes of four Lamiaceae essential oils, Pak. J. Bot. 43, 1315-1321.

[30] K. Carovic-Stanko, S. Orlic, O. Politeo, F. Strikic, I. Kolak, M. Milos and Z. Satovic (2010). Composition and antibacterial activities of essential oils of seven Icimum taxa, Food Chem. 119, 196-201.

[31] D. J. Daferera, B. N. Ziogas and M. G. Polissiou (2000). GC-MS analysis of essential oils from Greek aromatic plants and their fungitoxicity on Penicillium digitatum, J. Agric. Food Chem. 48, 2576-2581

[32] M. F. Arrigoni-Blank, A. R. Antoniolli, L. C. Caetano, D. A. Campos, A. F. Blank and P. B. Alves (2008). Antinociceptive activity of the volatile oils of Hyptis pectinata L. Poit. (Lamiaceae) genotypes, Phytomedicine 15, 334-339.

[33] N. Aligiannis, E. Kalpoutzakis, S. Mitaku and I. B. Chinou (2001). Composition and antimicrobial activity of the essential oils of two Origanum Species, J. Agric. Food Chem. 49, 4168-4170.

[34] A. Mohagheghzadeh, M. Shams-Ardakani and A. Ghannadi (2000). Volatile constituents of callus and flower-bearing tops of Zataria multiflora Boiss. (Lamiaceae), Flavour Fragr. J. 15, 373-376.

[35] A. Smelcerovic, M. Spiteller, A. P. Ligon, Z. Smelcerovic, and N. Raabe (2007). Essential oil composition of Hypericum L. species from Southeastern Serbia and their chemotaxonomy, Biochem. Syst. Ecol. 3599 113.

[36] H. I. Al-Jaber (2016). Variation in essential oil composition of Iris nigricans Dinsm. (Iridaceae) endemic to Jordan at different flowering stages, Arab. J. Chem. 9, S1190-S1196.

[37] S. Vasylievna Zhigzhitzhapova, L. Dorzhievna Radnaeva, Q. Gao, S. Chen and F. Zhang (2016). Chemical composition of volatile organic compounds of Artemisia vulgaris L. (Asteraceae) from the Qinghai-Tibet plateau, Ind. Crop. Prod. 83, 462-469.

[38] A. Venditti, C. Frezza, G. Salutari, M. di Cecco, G. Ciaschetti, A. Oliva, M. De Angelis, V. Vullo, M. Sabatino, S. Garzoli, F. Pepi, R. Ragno, M. Serafini and A. Bianco (2017). Composition of the essential Oil of Coristospermum cuneifolium and antimicrobial activity evaluation, Planta Med. Int. Open 4, 74-81.

[39] N. Gruda (2005). Impact of environmental factors on product quality of greenhouse vegetables for fresh consumption, Crit. Rev. Plant Sci. 24, 227-247.

[40] A. C. Figueiredo, J. G. Barroso, L. G. Pedro and J. J. C. Scheffer (2008). Factors affecting secondary metabolite production in plants: volatile components and essential oils, Flavour Fragance J. 23, 213-226.

[41] R. J. Fair and Y. Tor (2014). Antibiotics and bacterial resistance in the 21 st Century, Perspect. Medicin. Chem. 6, 25-64. 
[42] S. D. Cox, C. M. Mann, J. L. Markham, H. C. Bell, J. E. Gustafson, J. R. Warmingto and S. G. Wyllie (2000). The mode of antimicrobial action of the essential oil of Melaleuca alternifolia (tea tree oil), J. Appl. Microbiol. 88, 170-175.

[43] Ch. Gao, Ch. Tian, Y. Lu, J. Xu, J. Luo and X. Guo (2011). Essential oil composition and antimicrobial activity of Sphallerocarpus gracilis seeds against selected food-related bacteria, Food Control 22, 517-522.

[44] H. Nikaido (1985). Molecular basis of bacterial outer membrane permeability revisited, Microbiol. Rev. 49, $1-32$.

[45] M. M. Cowan (1999). Plants products as antimicrobial agents, Clin. Microbiol. Rev. 12, 564-582.

[46] J. Sikkema and de J. A. Bont (1994). Interactions of cyclic hydrocarbons with biological membranes, $J$. Biol. Chem. 269, 8022-8028.

[47] B. K. Tiwari and V. P. Valdramidis (2009). Application of natural antimicrobials for food preservation, $J$. Agric. Food Chem. 57, 5987-6000.

[48] T. Marrufo and F. Nazzaro (2013). Chemical composition and biological activity of the essential oil from leaves of Moringa oleifera Lam. cultivated in Mozambique, Molecules 18, 10989-11000.

[49] Y. Jiang, N. Wua, Y.J. Fua, W. Wang, M. Luo, C.J. Zhao, Y.G. Zu and X.L. Liu (2011). Chemical composition and antimicrobial activity of the essential oil of rosemary, Environ. Toxicol. Pharmacol. 32, 63-68.

[50] H. A. Ben and H. N. Ben (2013). Essential oil from Artemisia phaeolepis: chemical composition and antimicrobial activities, J. Oleo Sci. 62, 973-980.

[51] G.L. Xu, D. Geng, M. Xie, K.Y. Teng, Y.X. Tian, Z.Z. Liu, Ch. Yan, Y. Wang, X. Zhang, Y. Song, Y. Yang and G.M. She (2015). Chemical composition, antioxidative and anticancer activities of the essential oil: Curcumae rhizoma-Sparganii rhizoma, a traditional herb pair, Molecules 20, 15781-15796.

[52] S. Afoulous, H. Ferhout, E. G. Raoelison, A. Valentin, B. Moukarzel, F. Couderc and J. Bouajila (2011). Helichrysum gymnocephalum Essential oil: chemical composition and cytotoxic, antimalarial and antioxidant activities, attribution of the activity origin by correlations, Molecules 16, 8273-8291.

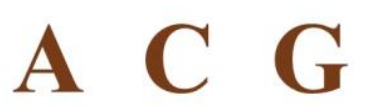

publications

(C) 2020 ACG Publications 